\title{
AEROBIC DECOLORIZATION OF AZO DYE ORANGE G BY A NEW YEAST ISOLATE Candida cylindracea SJL6
}

\author{
DESCOLORAÇÃO AERÓBICA DO AZO CORANTE ALARANJADO G POR UM \\ NOVO ISOLADO DA LEVEDURA Candida cylindracea SJL6
}

\author{
Tiago de Araújo Pinho ALCÂNTARA ${ }^{1}$; Juliana Mota OLIVEIRA ${ }^{1}$; \\ Norma Suely Evangelista-BARRETO ${ }^{1}$; Phellippe Arthur Santos MARBAC ${ }^{\mathbf{1}}$; \\ Marcia Luciana CAZETTA ${ }^{1,2}$
}

1. Programa de Pós-Graduação em Microbiologia Agrícola, Centro de Ciências Agrárias Ambientais e Biológicas - CCAAB, Cruz das Almas, BA, Brasil; 2. Centro de Ciências Exatas e Tecnológicas - CETEC. Universidade Federal do Recôncavo da Bahia - UFRB, Cruz das Almas, BA, Brasil. malucz@ufrb.edu.br

\begin{abstract}
Biodecolorization of the azo dye Orange $\mathrm{G}$ was investigated using a new strain of Candida cylindracea SJL6, isolated from freshwater samples of the Subaé river in Bahia state, Brazil. Strain SJL6 was identified as C. cylindracea on the basis of $26 \mathrm{~S}$ rDNA region. The various parameters of dye decolorization and cell growth were studied, including the Orange $\mathrm{G}$ dye concentration $(100$ to $500 \mathrm{ppm})$, temperature $\left(20\right.$ to $\left.40{ }^{\circ} \mathrm{C}\right)$, glucose concentration $(0$ to $5 \%$ ), and initial $\mathrm{pH}$ (3 to 8). Biotoxicity tests were performed using shrimp (Artemia salina) to determine the lethal concentration $\left(\mathrm{LC}_{50}\right)$ and onion bulbs (Allium cepa) to determine the cytotoxic and genotoxic effects of both Orange $\mathrm{G}$ dye and metabolites formed after decolorization. Up to $90 \%$ of decolorization of the Orange $\mathrm{G}$ dye at $500 \mathrm{ppm}$ was achieved by C. cylindracea SJL6 at $30{ }^{\circ} \mathrm{C}, \mathrm{pH} 3$, and $1 \%$ glucose. However, the biotoxicity tests showed that there was increased toxicity after decolorization, suggesting partial Orange $\mathrm{G}$ dye degradation and production of toxic metabolites.
\end{abstract}

KEYWORDS: Biodegradation. Fungus. Dyes.

\section{INTRODUCTION}

The presence of residues in textile effluents causes significant impacts on the total organic carbon, biochemical oxygen demand (BOD), chemical oxygen demand (COD), suspended solids, salinity, $\mathrm{pH}$, and color, in addition to the recalcitrant nature of azo dyes (FARYAL; HAMEED, 2005; SAVIN; BUTNARU, 2008). The high values of BOD and COD can result in the consumption of dissolved oxygen, causing the death of fish and other aquatic organisms (VON SPERLING, 1996). Furthermore, azo dyes when metabolized by particular enzymes, may generate aromatic amines, which are known for their high toxicity, mutagenicity, and carcinogenicity (SOLÍS et al., 2012).

All this has raised growing concerns and prompted several studies in different fields of knowledge in an attempt to develop effective and low-cost technologies for the removal of dyes from textile effluents. Physical and chemical treatments have been the most widely used; however, they usually require high costs and are not able to completely degrade the molecules, generating significant amounts of chemical sludge, which creates a second pollution problem, waste disposal (ANJANEYULU; CHARY, 2005; SARATALE et al., 2009; BAFANA et al., 2011).
Azo dyes account for $70 \%$ of all dyes used in the textile industry (TONY et al., 2009). The success of the wide use of these dyes is related to their easy synthesis, cost-effectiveness, stability, and great structural variety, which enables a wide range of colors and applications. Thus, in addition to the textile industry, these dyes are widely used in the paper, food, leather, cosmetics, and medical industries (CHANG et al., 2004; TELKE et al., 2008).

Bioremediation has been considered an environment friendly and cost-competitive approach that produces less sludge and is able to generate end-products of low toxicity or even achieve total mineralization of compounds (RAI et al., 2005). In this context, many microorganisms have been selected every day for the development of new treatments.

Due to their enzymatic apparatus, fungi have a great potential for decolorization of azo dyes (MORTARELL et al., 2012). Through oxidative and ligninolytic non-specific enzyme systems, these microorganisms are able to mineralize various types of synthetic dyes (YANG et al., 2005). However, several factors hamper the use of filamentous fungi in industrial waste treatment, such as stringent conditions for enzyme production, risk of bacterial contamination under non-sterile conditions of wastewater treatment, and slow growth compared to 
that of unicellular organisms, in addition to the production of mycelia, which often makes fungi less adaptable to effluent treatment conditions (ASKU; DÖNMEZ, 2003; YU; MEN, 2005).

The use of yeasts presents several biotechnological advantages, not only because of their rapid growth, but also because of their resistance to unfavorable environments and high efficiency in azo dye decolorization (MORTARELL et al, 2012; YANG et al., 2008; LIU et al., 2011; PAJOT et al., 2011; TAN et al., 2014).

Therefore, the aim of this work was to evalaute various culture parameters for decolorization of the Orange $\mathrm{G}$ azo dye by a new strain of Candida cylindracea SJL6, as well as to evaluate the toxicity of final products of the degradation process.

\section{MATERIAL AND METHODS}

The azo dye used in this study was Orange G (C.I. Name: Acid Orange 10; Sigma-Aldrich, St. Louis, MO, USA). A 10,000 ppm stock solution was prepared by dissolving the dye in distilled water and sterilizing by vacuum filtration $(0.22-\mathrm{mm}$ filter, Millipore Corp., Bedford, MA, USA).

\section{Culture medium}

The modified Normal Decolorization Medium (NDM) was used for the experiments, which consisted of (\%): yeast extract, 0.25; $\mathrm{KH}_{2} \mathrm{PO}_{4}, 0.5 ; \mathrm{MgSO}_{4} \cdot 7 \mathrm{H}_{2} \mathrm{O}, 0.05 ; \mathrm{CaCl}_{2} \cdot 2 \mathrm{H}_{2} \mathrm{O}$, 0.013; and glucose, 2 (RAMALHO et al., 2004). After sterilization at $121{ }^{\circ} \mathrm{C}$ for $20 \mathrm{~min}$, Orange $\mathrm{G}$ was added to the medium at different concentrations (100, 200, 300, 400, and 500 ppm). The pH was adjusted to 5.0 with orthophosphoric acid.

\section{Molecular identification of the yeast}

DNA extraction was performed according to Sampaio et al. (2001) and Almeida (2005). Molecular characterization was performed by sequencing of the D1/D2 region of $26 \mathrm{~S}$ ribosomal DNA using the NL1 GCATATCAATAAGCGGAGGAAAAG-3') and NL4 (5'-GGTCCGTGTTTCAAGACGG-3') primers (O'DONNEL, 1993). For the polymerase chain reaction (PCR), we used the following reagents and concentrations: $10 \mathrm{ng}$ of DNA, $1 \times$ enzyme buffer for Taq DNA polymerase, $3.7 \mathrm{mM} \mathrm{MgCl}_{2}, 0.6$ $\mathrm{pmol} / \mu \mathrm{L}$ dNTPs, $0.4 \mathrm{pmol} / \mu \mathrm{L}$ each primer, and $5 \mathrm{U}$ of Taq DNA polymerase, with the final volume adjusted to $50 \mu \mathrm{L}$ with sterile ultra-pure water. DNA of Saccharomyces cerevisiae (10 ng) was used as a positive control. Amplification was performed in a
peqSTAR 96× Universal Gradient thermal cycler (PeqLab, Erlangen, Germany) programmed for an initial denaturation at $94{ }^{\circ} \mathrm{C}$ for $3 \mathrm{~min}$, followed by 28 cycles of denaturation $\left(94{ }^{\circ} \mathrm{C}, 30 \mathrm{~s}\right)$, annealing $\left(58^{\circ} \mathrm{C}, 1 \mathrm{~min}\right)$, and extension $\left(72{ }^{\circ} \mathrm{C}, 2 \mathrm{~min}\right)$ and a final extension at $72{ }^{\circ} \mathrm{C}$ for $5 \mathrm{~min}$. The amplified products were separated on a $0.8 \%$ agarose gel, stained with ethidium bromide, and visualized under ultraviolet light. The PCR fragments were purified using a GFX PCR kit (Amersham Biosciences, Piscataway, NJ, USA), and then the amplicons were sequenced on an automatic sequencer ABI 310 (Applied Biosystems, Foster City, CA, USA) at the Molecular Genetics Laboratory of Federal University of Recôncavo da Bahia. The second round of sequencing was performed using an ABI PRISM 3100 genetic analyzer (Applied Biosystems) by ACTGene Molecular Analysis LTDA (The Rio Grande do Sul, Brazil). The sequences obtained were compared with those available in the GenBank database using the Basic Local Alignment Search Tool (BLAST) at http://www.ncbi.nlm.nih.gov.

\section{Decolorization assays}

Assays were performed in 250-mL Erlenmeyer flasks containing $50 \mathrm{~mL}$ of NDM at varying culture conditions: the dye concentration (100-500 ppm), glucose concentration (0-5\%), pH (3-8), and temperature $\left(20-40^{\circ} \mathrm{C}\right)$. After incubation at $150 \mathrm{rpm}$ for $24 \mathrm{~h}, 2-\mathrm{mL}$ aliquots were taken from the flasks and centrifuged at 5,000 rpm for $10 \mathrm{~min}$. The supernatant obtained was used to analyze both decolorization rate and toxicity, while the biomass was used to determine cellular growth. All assays were performed in triplicate. As the inoculum, $5 \mathrm{~mL}$ of a cellular suspension (optical density at $550 \mathrm{~nm}=$ 0.8) was used, which was prepared from a 24-h culture grown in NDM.

\section{Analytical method}

The decolorization rate was determined by spectrophotometry at $476 \mathrm{~nm}$ and calculated using the following equation:

Decolorization $(\%)=(\mathrm{A}-\mathrm{B}) / \mathrm{A} \times 100$, where $A$ and $B$ represent the initial and final absorbance of the dye, respectively.

Cellular growth was determined by measuring optical density at $550 \mathrm{~nm}$.

\section{Biotoxicity tests}

\section{Acute toxicity test using Artemia salina}

The acute biotoxicity test was performed with the nauplii of $A$. salina, according to Matthews (1995), with some modifications. For hatching, $1 \mathrm{~g}$ of A. salina cysts was added to $500 \mathrm{~mL}$ of artificial 
seawater (30 ppt). The cysts were kept at a constant agitation by air pumping for $24 \mathrm{~h}$ at room temperature. Then, 10 nauplii of A. salina were transferred to test tubes containing $10 \mathrm{~mL}$ of artificial seawater and Orange $G$ dye (positive control) or different concentrations $(2.08,4.2,8.3$, $16.6,25,33,50$, and $75 \%$ ) of the supernatant obtained after the decolorization process and incubated at room temperature for $24 \mathrm{~h}$. Artificial seawater was used as a negative control, and all tests were performed in triplicate. The results were obtained by counting the number of alive A. salina nauplii in each test tube. The calculation of the lethal concentration $\left(\mathrm{LC}_{50}\right)$ was performed using the Spearman-Karber Trimmed program (AN, 2006).

\section{Biotoxicity test using onion (Allium cepa)}

The tests using onion bulbs were performed according to Fiskesjö (1985), modified. Nonsprouted onion bulbs of the same origin, approximately $2 \mathrm{~cm}$ in size, with external white cataphylls, were purchased at a local market. Before the test, dry external cataphylls were removed without damaging the root meristem, and the bulbs were washed under running water. To avoid dehydration of primary cells, the bulbs were placed in distilled water and kept in the dark for $48 \mathrm{~h}$. Distilled water was changed daily. After two days, bulbs with the size of 1.5 to $2.0 \mathrm{~cm}$ were selected. Five bulbs were used for each treatment. The bulbs were placed in test tubes, with their roots in contact with the supernatant $(20 \mathrm{~mL})$ obtained after the decolorization process. The Orange $\mathrm{G}$ dye solution was a positive control, and distilled water was a negative control. After $24 \mathrm{~h}$ of exposure, the roots were removed, kept in Carnoy's fixative solution for $24 \mathrm{~h}$, and then stored in ethanol (70\%) under refrigeration until slide preparation.

For the slide preparation, roots were removed from ethanol, washed, and hydrolyzed in 1 $\mathrm{M} \mathrm{HCl}$ at $60{ }^{\circ} \mathrm{C}$ for $8 \mathrm{~min}$. Subsequently, a drop of acetic acid $(45 \%)$ was added to a slide, and the tip was removed from a root, then covered with a coverslip, and crushed. The slide-coverslip assembly was frozen at $-80{ }^{\circ} \mathrm{C}$ for $5 \mathrm{~min}$, then the coverslip was removed, and the material was stained with $10 \%$ Giemsa stain for $2 \mathrm{~min}$. The root material on the blade was observed under an optical microscope at a $400 \times$ magnification. About 5,000 cells were analyzed per treatment. The following parameters were observed: (A) a mitotic index (MI) (1,000 cells per bulb); (B) chromosomal aberrations (CAs) in the mitotic cycle (1,000 cells per bulb); and (c) the presence of micronuclei $(1,000$ cells per bulb). The data were analyzed with the Assistat Software, version 7.7, using analysis of variance, followed by Turkey's test.

\section{RESULTS AND DISCUSSION}

\section{Molecular identification}

A 616-nucleotide sequence of the D1/D2 region of strain SJL6 showed 99\% identity with the sequences of the D1/D2 domain of C. cylindracea (Figure 1).

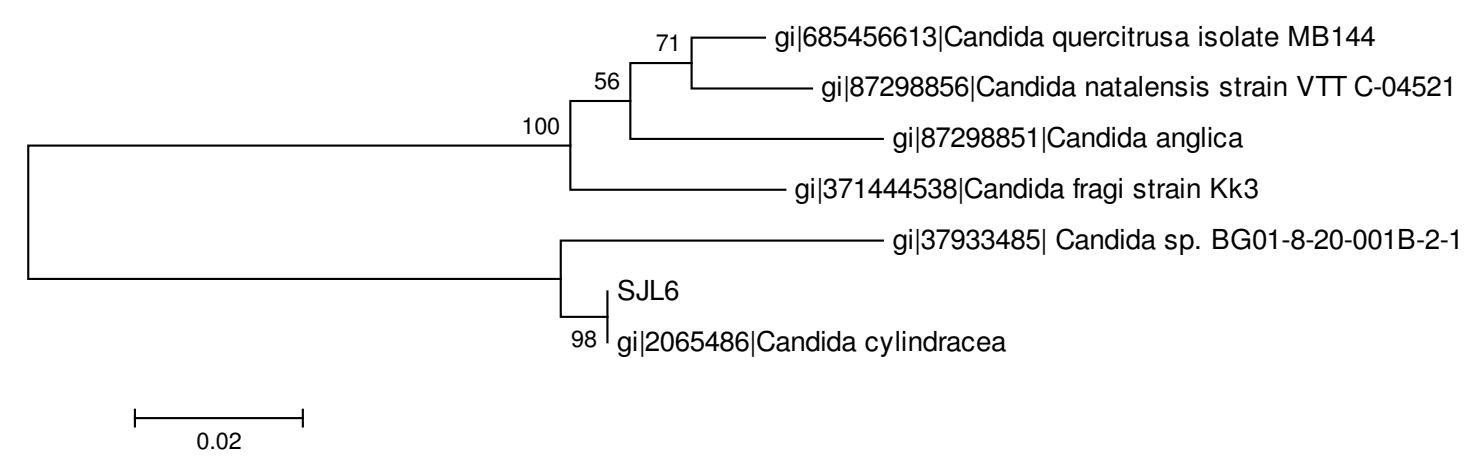

Figure 1. Maximum likelihood phylogenetic tree inferred from the alignment of the D1/D2 region sequences of the yeast rDNA subunit constructed in the MEGA 6 program. The best model selected by the program was the Tamura-Nei + Gamma (TN93 + G) model with partial deletion of missing data and confidence level of 1000 bootstrap repeats.

\section{Effects of various parameters on the Orange $G$ decolorization rate and cellular growth of $C$. cylindracea SJL6}

\section{Initial dye concentration}

C. cylindracea SJL6 was able to remove more than $90 \%$ of the color up to an Orange G concentration of $500 \mathrm{ppm}$ after $24 \mathrm{~h}$, and only a 
small biomass reduction occurred with the increasing Orange $G$ concentrations. Thus, it is possible to conclude that $C$. cylindracea SJL6 proved to be quite tolerant to high concentrations of the dye (Figure 2).

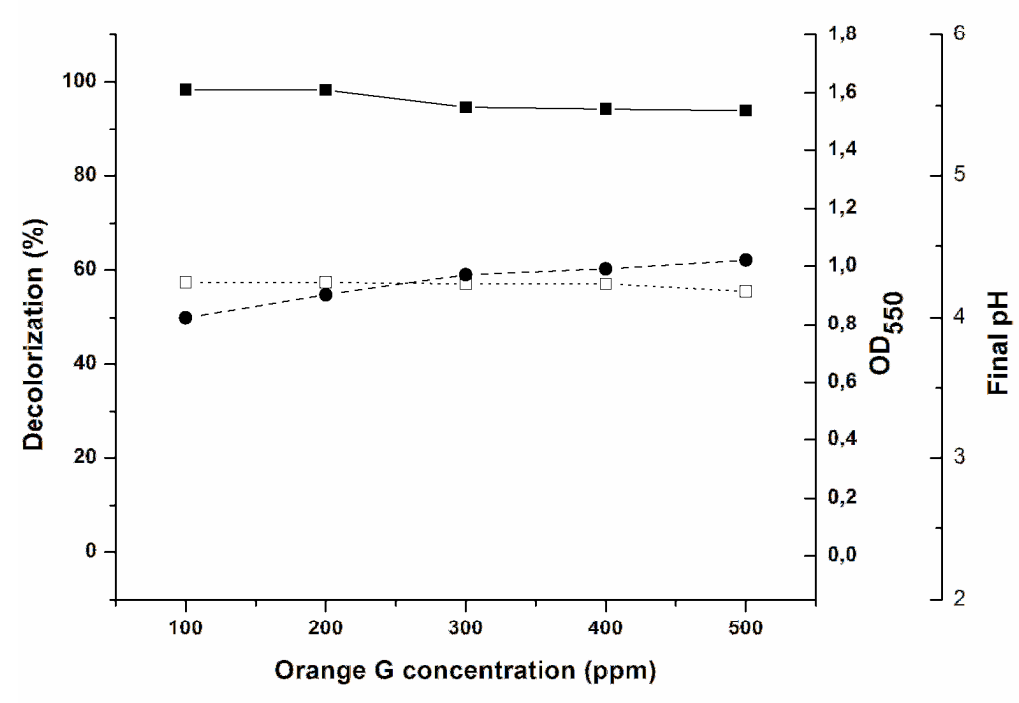

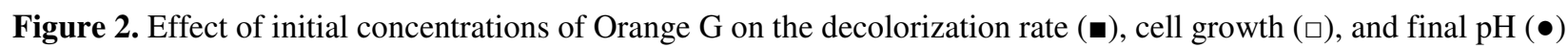

Results obtained by other authors have shown an inverse relationship between initial concentrations and dye decolorization. Pseudozyma rugulosa Y-48 and Candida krusei G-1 decolored 99\% of Reactive Bright Red L-2BP at 200 ppm after $24 \mathrm{~h}$, with the decolorization gradually decreasing as the dye concentrations increased (YU; MEN, 2005). In another study, Candida tropicalis TL-F1 was able to achieve a decolorization rate of more than $97 \%$ with the Acid Brilliant Scarlet GR dye in the concentration range from 20 to 100 ppm after $24 \mathrm{~h}$; however, there was a rate reduction to less $80 \%$ at higher dye concentrations (120 and $140 \mathrm{ppm}$ ) (TAN et al., 2014). Issatchenkia orientalis JKS6 was able to decolorize up to $99 \%$ of the Reactive Black 5 dye at $500 \mathrm{ppm}$ after $36 \mathrm{~h}$; however, the decolorization rate decreased to less than $40 \%$ at a 1,000 ppm dye concentration (JAFARI et al., 2014). The decrease in the decolorization rate with an increasing dye concentration suggests a toxic action by dye intermediate metabolites produced after cleavage of the chromophore group (WANG et al., 2009). Textile effluents show variations in residual dye concentrations, and therefore, the ability of microorganisms to degrade dyes in a wide range of concentrations becomes an important factor for effective biodegradation (PARSHETTI et al., 2010; AYED et al., 2011).

\section{Glucose concentration}

Figure 3 shows the effects of glucose concentrations on the Orange $\mathrm{G}$ dye decolorization.
The results showed that $C$. cylindracea SJL6 was unable to perform decolorization in the absence of an external source of carbon and energy. Although there are reports of yeasts that can use a dye as a sole source of carbon and/or nitrogen for dye degradation, this process is highly associated with the cell growth and primary metabolism (LUCAS et al., 2006; YANG et al., 2008; PAJOT et al., 2011; MORTARELL et al., 2012). Therefore, yeasts do not generally grow without glucose or any other readily metabolizable carbon source (SOLÍS et al., 2012).

In this work, the increase of glucose concentrations showed no significant effect on both decolorization rate and cellular growth, which remained constant at the glucose concentrations from $1 \%$ to $5 \%$. These results are very interesting since low carbon source concentrations reduce the costs of developing biodegradation processes. Moreover, high glucose concentrations in the medium can inhibit dye degradation since microorganisms tend to use an external source of energy instead of a dye (QU et al., 2012). However, no such inhibition was observed in this study up to the maximum glucose concentration studied (5\%).

For the yeasts Debaryomyces polymorphus and $C$. tropicalis, Reactive Black 5 dye degradation was highly dependent on the glucose concentration in the medium. Thus, the color removal increased from $76.4 \%$ and $92.7 \%$, respectively, after $60 \mathrm{~h}$ to $100 \%$ between $18 \mathrm{~h}$ and $24 \mathrm{~h}$ after rising glucose 
concentration from $0.5 \%$ to $1 \%$ (YANG et al., 2008).

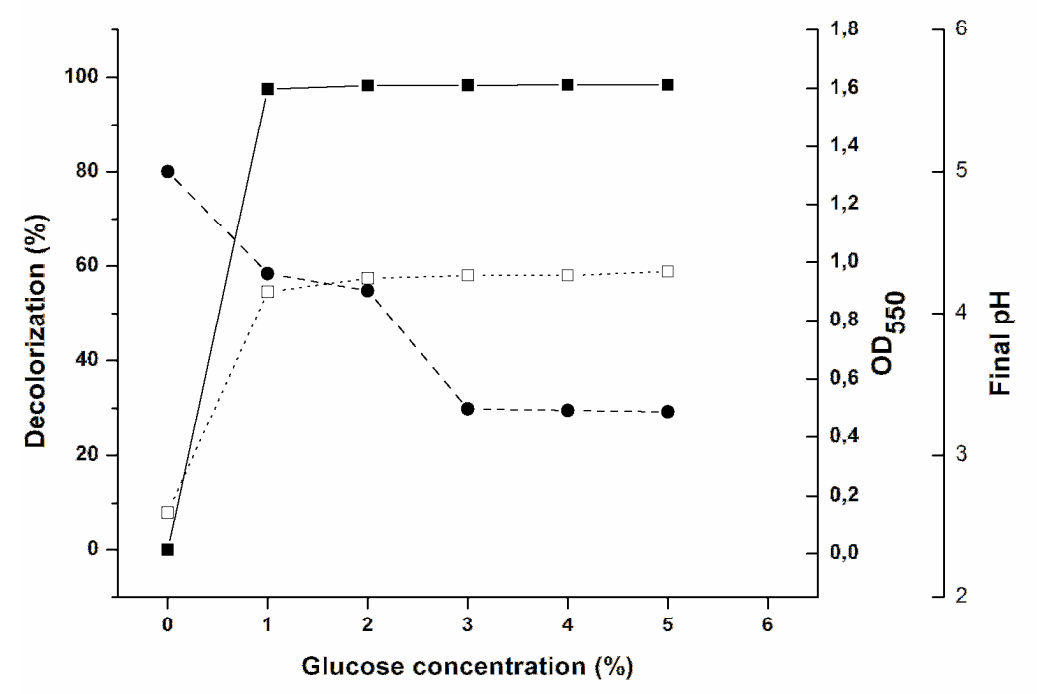

Figure 3. Effect of glucose concentrations on the Orange G dye (200 ppm): decolorization rate (घ), cell growth $(\square)$, and final $\mathrm{pH}(\bullet)$.

The optimal glucose concentration was reported to be between 0.5 and $1 \%$ for several yeasts such as Pichia sp. TCL upon decolorization of the Acid Red B dye (100 ppm) (QU et al., 2012), I. orientalis JKS2 upon decolorization of the Reactive Black 5 dye (JAFARI et al., 2014), and C. tropicalis TL-F1 upon decolorization of the Acid Bright Scarlet GR dye (100 ppm) (TAN et al., 2014). In this study, an increased glucose concentration favored the cell growth, and a slight increase in biomass was observed, followed by a decrease in $\mathrm{pH}$. The decrease in $\mathrm{pH}$ occurred due to glucose metabolism and positively influenced the dye decolorization since yeasts, in general, adapt better to acid environments.

\section{pH}

The decolorization rate was above $98 \%$ in the $\mathrm{pH}$ range between 3 and 6 (Figure 4) and drastically decreased at $\mathrm{pH} 7$ and 8 . The cell growth was not affected by the $\mathrm{pH}$ variation, although it was slightly better in the $\mathrm{pH}$ range between 4 and 5 . These results are interesting for the development of biodecolorization processes using $C$. cylindracea SJL6 since acidic $\mathrm{pH}$ inhibits the growth of others microorganisms such as bacteria. It was not possible to correlate the cell growth with the decolorization rate, which suggests that the relationship between $\mathrm{pH}$ and decolorization is associated with optimal conditions for the performance and production of enzymes involved in the degradation process.

It is generally known that the maximum fungal growth and the maximum activity of ligninolytic enzymes involved in azo dye decolorization are observed at a low $\mathrm{pH}$ (SHAH; PATEL, 2014). The same has been described for biodegradation of different dyes by yeasts (JADHAV et al., 2008; LIU et al., 2011; TAN et al., 2014). Enzymes such as manganese peroxidase $(\mathrm{MnP})$, lignin peroxidase (LiP), NADHdichlorophenol indophenol reductase, and azoreductases are some of the major enzymes involved in dye biodegradation by yeasts (YANG et al., 2005; LUCAS et al., 2006; JADHAV et al., 2008; WAGHMODE et al., 2011).

\section{Temperature}

The maximum Orange $\mathrm{G}$ decolorization rate and cell growth were observed in the temperature range from $20{ }^{\circ} \mathrm{C}$ to $30^{\circ} \mathrm{C}$. However, decolorization ceased completely at temperatures of $35{ }^{\circ} \mathrm{C}$ and above, accompanied by a sharp decrease in cell growth (Figure 5). These results can be explained by a loss of cell viability and/or by denaturation of the enzymes responsible for the dye decolorization (WANG et al., 2009).

The temperature effect on decolorization does not follow a pattern and varies according to the characteristics inherent to the microorganisms and/or the enzymes involved in the process. For yeasts, the best results are reported at temperatures in the range from $25{ }^{\circ} \mathrm{C}$ to $32{ }^{\circ} \mathrm{C}$ (ERTUĞRUL et al., 2008; CHARUMATHI; DAS, 2010; GRASSI et al., 2011; LIU et al., 2011; JAFARI et al., 2014). 


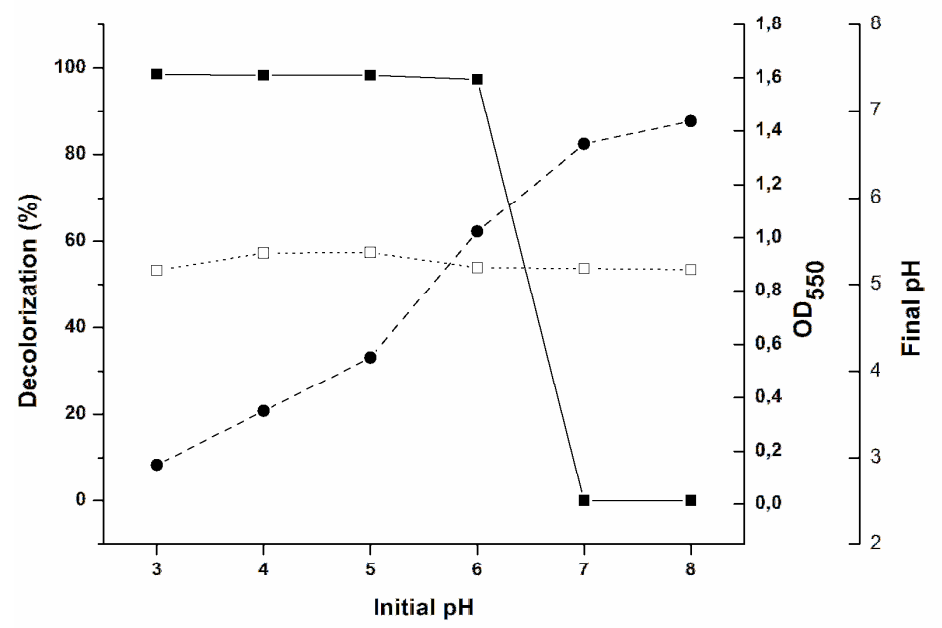

Figure 4. Effect of initial pH on the decolorization rate of Orange G (200 ppm) (a), cell growth ( $\square)$, and final $\mathrm{pH}(\bullet)$.

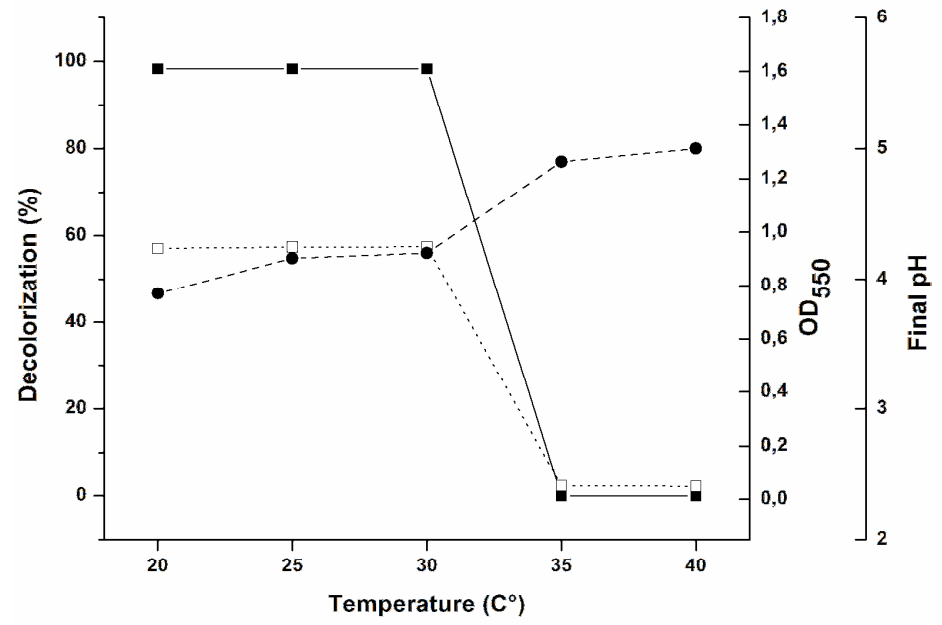

Figure 5. Effect of the temperature on the decolorization rate of Orange G (200 ppm) (घ), cell growth ( $\square$ ), and final $\mathrm{pH}(\bullet)$.

\section{Biotoxicity tests}

The toxicity tests were performed using the nauplii of the brine shrimp A. salina as a quick, simple, and inexpensive test, which provides a good indication of the acute toxicity for several compounds and is widely used to determine the toxicity of dyes (PRASAD; RAO, 2013; IQBAL \& BHATTI, 2014; PUNZI et al., 2015). The results obtained in this study showed that the decolorization products reached a lethal concentration $\left(\mathrm{LC}_{50}\right)$ at $17.45 \%$. However, in assays containing only the Orange $G$ dye at different concentrations, no mortality of A. salina was observed. These results suggest that the cleavage of the chromophore group produced toxic intermediates (PUVANESWARI et al., 2006). It is common to see the reports about increased toxicity after dye decolorization processes. Silva et al. (2012) analyzed the discoloration of the Phthalocyanine Reactive Blue 21 dye by peroxidase of turnip and found that the hydrolysis of the chromophore group increased toxicity after enzyme treatment. Almeida and Corso (2014) also observed that the inhibition of the lettuce (Lactuca sativa) seed germination increased from 5 to $50 \%$, compared with that caused by the untreated dye, after the Procion Red MX-5B dye was decolorized by Aspergillus terreus, indicating incomplete dye degradation and production of toxic intermediates.

To confirm the above results, toxicity tests were performed using onions because they are a good indicator of cytotoxicity, genotoxicity, and 
mutagenicity, besides providing a cheap, fast, and sensitive method for toxicity monitoring. According to the results (Table 1), cytotoxicity increased after the Orange $\mathrm{G}$ decolorization. Cellular aberrations were observed as anaphase bridges, chromosome fragments, sticky chromosomes in the metaphase, nuclear abnormalities, and the presence of micronuclei, which were evaluated separately. All
MI tests differed statistically. Regarding the CA index and the presence of micronuclei, there were differences between the treatments and control, but not among the treatments. No significant reduction in MI, caused by the exposure of onion bulbs to the Orange $\mathrm{G}$ dye, was observed; on the other hand, a higher reduction of MI occurred after dye decolorization $(24 \mathrm{~h})$.

Table 1. Total number of cell in interphase and in division: mitotic index (MI), chromosomal aberrations rate (CA) and micronucleus index (MN)

\begin{tabular}{|c|c|c|c|c|c|}
\hline Treatments & $\begin{array}{c}\text { Interphase } \\
\text { cells }\end{array}$ & $\begin{array}{l}\text { Cells in } \\
\text { division }\end{array}$ & $\mathrm{MI}(\%) * *$ & $\mathrm{CA}(\%) * *$ & $\mathrm{MN}(\%)^{*}$ \\
\hline Control & 4133 & 867 & $17.34 \pm 0,5^{\mathrm{a}}$ & $0.06 \pm 0.09^{b}$ & $0 \pm 0$ \\
\hline Orange G & 4572 & 428 & $8.56 \pm 0,62^{b}$ & $0.56 \pm 0.15^{\mathrm{a}}$ & $0.2 \pm 0.19^{\mathrm{a}}$ \\
\hline Supernatant & 4769 & 231 & $4.62 \pm 0,76^{\mathrm{c}}$ & $0.46 \pm 0.21^{\mathrm{a}}$ & $0.2 \pm 0.10^{\mathrm{a}}$ \\
\hline
\end{tabular}

The increased toxicity after decolorization in both tests can be attributed to the incomplete dye degradation, indicating a biotransformation process. The metabolites produced after dye decolorization can be more toxic in many cases than the original dye molecule, and their toxicity is commonly attributed to aromatic amines, which are often released after reduction of the azo dye linkage (PINHEIRO et al., 2004; BAFANA et al., 2011; SOLÍS et al., 2012). The presence of 4aminoacetanilide and 5-acetamido-2-amino-1hydroxy-3,6-naphtalene disulfonic acid was reported to be responsible for the increased toxicity in rats after Violet dye degradation by the bacterium Pseudomonas putida (BEN MANSOUR et al., 2010).

According to the literature, the Orange $G$ dye is not easily degraded by microorganisms. Fungi such as Thelephora sp. and Pleurotus sajorcaju, which present a recognized potential for the decolorization of different azo dyes, removed only $30 \%$ and $50 \%$ of the color, respectively (CHAGAS; DURRANT, 2001; SELVAN et al., 2003).

The Orange $G$ decolorization rate by Bacillus megaterium was above $94.5 \%$ (TRIPATHI; SRIVASTAVA, 2014). However, the metabolites produced were identified as naphthalene, aldehyde derivative compounds, and phenylhydrazine, which are known for their toxicity by oral, dermal, and inhalation routes, in addition to causing skin and eye irritations and being directly involved in hemolytic anemia in vertebrates (SHUKLA et al., 2012).

Longer-time fermentation could contribute to increased dye mineralization and reduce or eliminate the metabolite toxicity. In addition, the use of microbial consortia is highly recommended to obtain complete dye degradation.

\section{CONCLUSIONS}

The yeast $C$. cylindracea SLJ6 was efficient in Orange $G$ dye decolorization, showing good tolerance of high dye concentrations. However, the results suggested incomplete biodegradation, and the metabolites produced after decolorization were more toxic than the original dye molecule, underscoring the need for additional studies to identify the metabolites produced. In addition, new approaches are necessary to reduce the production of potentially toxic metabolites, such as the use of microbial consortia.

\section{ACKNOWLEDGEMENTS}

The authors are grateful to CAPES and FAPESB for financial support for the realization of this work.

RESUMO: A biodescoloração do corante Alaranjado $\mathrm{G}$ foi investigada utilizando um novo isolado de Candida cylindracea SJL6, isolado de amostras de água do Rio Subaé, Bahia, Brasil. A linhagem SJL6 foi identificada como Candida cylindracea com base na região $26 \mathrm{~S}$ do rDNA. Os parâmetros estudados na descoloração do corante e 
crescimento celular foram: concentração do Alaranjado G (100 a 500 ppm), temperatura $\left(20\right.$ a $\left.40{ }^{\circ} \mathrm{C}\right)$, concentração de glicose $(0$ a $5 \%$ ) e pH inicial (3 a 8). Os testes de biotoxicidade foram realizados utilizando o microcrustáceo Artemia salina para determinar a concentração letal $\left(\mathrm{L}_{50}\right)$ e bulbos de cebola (Alium cepa) para determinar os efeitos citotóxicos e genotóxicos tanto do corante alaranjado $\mathrm{G}$ quanto dos metabólitos produzidos após a descoloração. Uma taxa de descoloração acima de $90 \%$ foi atingida a 500 ppm por C. cylindracea SJL6 a $30^{\circ} \mathrm{C}$, pH 3 e $1 \%$ de glicose. Entretanto, os testes de biotoxicidade mostraram que ocorreu um aumento da toxicidade após a descoloração, o que sugere uma degradação parcial da molécula do corante Alaranjado G e produção de metabólitos tóxicos.

PALAVRAS-CHAVE: Biodegradação. Fungos. Corantes

\section{REFERENCES}

AKSU, Z.; DÖNMEZ, G. A comparative study on the biosorption characteristics of some yeasts for Remazol Blue reactive dye. Chemosphere, v. 50, n. 8, p. 1075-1083, 2003. https://doi.org/10.1016/S00456535(02)00623-9

ALMEIDA, J. M. Yeast community survey in the Tagus estuary. FEMS Microbiology Ecology, v. 53, n. 2, 295-303, 2005. https://doi.org/10.1016/j.femsec.2005.01.006

AN, Y. J. Assessment of comparative toxicities of lead and copper using plant assay. Chemosphere, v. 62 , n. 8, p. 1359-1365, 2006. https://doi.org/10.1016/j.chemosphere.2005.07.044

ANJANEYULU, Y.; CHARY, N. S.; RAJ, D. S. S. Decolourization of industrial effluents-available methods and emerging technologies-a review. Reviews in Environmental Science and Biotechnology, v. 4, n. 4, p. 245-273, 2005. https://doi.org/10.1007/s11157-005-1246-z

AYED, L.; MAHDHI, A.; CHEREF, A.; BAKHROUF, A. Decolorization and degradation of azo dye methyl red by an isolated Sphingomonas paucimobilis: biotoxicity and metabolites characterization. Desalination, $\mathrm{v}$. 274, p. 272-277. https://doi.org/10.1016/j.desal.2011.02.024

BAFANA, A.; DEVI, S. S.; CHAKRABARTI, T. Azo dyes: past, present and the future. Environmental Reviews, v. 19, n. NA, p. 350-371, 2011. https://doi.org/10.1139/a11-018

BEN MANSOUR, H.; AYED-AJMI, Y.; MOSRATI, R.; CORROLER, D.; GHEDIRA, K..; BARILLIER, D.; \& CHEKIR-GHEDIRA, L. Acid violet 7 and its biodegradation products induce chromosome aberrations, lipid peroxidation, and cholinesterase inhibition in mouse bone marrow. Environmental Science and Pollution Research, V. 17, n. 7, p. 1371-1378, 2010. https://doi.org/10.1007/s11356-010-0323-1

CHAGAS, E. P.; DURRANT, L. R. Decolorization of azo dyes by Phanerochaete chrysosporium and Pleurotus sajorcaju. Enzyme and Microbial Technology, v. 29, n. 8, 473-477, 2001. https://doi.org/10.1016/S0141-0229(01)00405-7

CHANG, J. S.; CHEN, B.; LIN, Y. S. Stimulation of bacterial decolorization of an azo dye by extracellular metabolites from Escherichia coli strain NO3. Bioresource Technology, v. 91, n. 3, p. 243-248, 2004. https://doi.org/10.1016/S0960-8524(03)00196-2

CHARUMATHI, D.; DAS, N. Bioaccumulation of synthetic dyes by Candida tropicalis. growing in sugarcane bagasse extract medium. Advances in Biological Research, v. 4, p. 233-240, 2010.

ERTUĞRUL, S.; BAKIR, M.; DÖNMEZ, G. Treatment of dye-rich wastewater by an immobilized thermophilic cyanobacterial strain: Phormidium sp. Ecological Engineering, v. 32, n. 3, p. 244-248, 2008. HTTPS://doi.org/10.1016/j.ecoleng.2007.11.011 
FARYAL, R. A. N. I.; HAMEED, A.. Isolation and characterization of various fungal strains from textile effluent for their use in bioremediation. Pakistan Journal of Botany, v. 37, n. 4, p. 1003, 2005.

FISKESJÖ, G. The allium test as a standard in environmental monitoring. Hereditas, v. 102, n. 1, p. 99-112, 1985. https://doi.org/10.1111/j.1601-5223.1985.tb00471.x

GRASSI, E.; SCODELLER, P.; FILIEL, N.; CARBALLO, R.; LEVIN, L. Potential of Trametes trogii culture fluids and its purified laccase for the decolorization of different types of recalcitrant dye without the addition of redox mediators. International Biodeterioration and Biodegradation. v. 65, p. 635-643, 2011.

https://doi.org/10.1016/j.ibiod.2011.03.007

IQBAL, M.; BHATTI, I. A. Re-utilization option of industrial wastewater treated by advanced oxidation process. Journal of Agriculture Sciences, v. 51, n. 4, p. 1041-1047, 2014.

JADHAV, S. U.; KALME, S. D.; GOVINDWAR, S. P. Biodegradation of Methyl Red by Galactomyces geotrichum MTCC 1360. International Biodeterioration \& Biodegradation, v. 62, n. 2, p. 135-142, 2008. https://doi.org/10.1016/j.ibiod.2007.12.010

JAFARI, N.; SOUDI, M. R.; KASRA-KERMANSHAHI, R. Biodecolorization of textile azo dyes by isolated yeast from activated sludge: Issatchenkia orientalis JKS6. Annals of Microbiology, v. 64 , n. 2, p. 475-482, 2014. https://doi.org/10.1007/s13213-013-0677-y

KNAPP, J. S.; NEWBY, P. S.; REECE, L. P. Decolorization of dyes by wood-rotting basidiomycete fungi. Enzyme and Microbial Technology, v. 17, n. 7, p. 664-668, 1995. https://doi.org/10.1016/01410229(94)00112-5

LIU, X.; ZHANG, J.; JIANG, J.; LI, R.; XIE, Z.; LI, S. Biochemical degradation pathway of reactive blue 13 by Candida rugopelliculosa HXL-2. International Biodeterioration \& Biodegradation, v. 65, n. 1, p. 135141, 2011. https://doi.org/10.1016/j.ibiod.2010.10.005

LUCAS, M. S.; AMARAL, C.; SAMPAIO, A.; PERES, J. A.; DIAS, A. A. Biodegradation of the diazo dye Reactive Black 5 by a wild isolate of Candida oleophila. Enzyme and Microbial Technology, v. 39, n. 1, p. 51-55, 2006. https://doi.org/10.1016/j.enzmictec.2005.09.004

MARTORELL, M. M.; PAJOT, H. F.; DE FIGUEROA, L. I. C. Dye-decolourizing yeasts isolated from Las Yungas rainforest. Dye assimilation and removal used as selection criteria. International Biodeterioration \& Biodegradation, v. 66, n. 1, p. 25-32, 2012. https://doi.org/10.1016/j.ibiod.2011.10.005

MATTHEWS, R. S. Artemia salina as a test organism for measuring superoxide-mediated toxicity. Free Radical Biology and Medicine, v.18, n.5, p.919-922, 1995. https://doi.org/10.1016/0891-5849(94)00205-X

PAJOT, H. F.; DELGADO. O.D.; FIGUEROA, L.I.C.; FARIÑA, J.I. Unraveling the decolourizing ability of yeast isolates from dye-polluted and virgin environments: an ecological and taxonomical overview. Antonie van Leeuwenhoek, v. 99, n. 3, p. 443-456, 2011. https://doi.org/10.1007/s10482-010-9495-4

PARSHETTI, G. K.; TELKE, A. A.; KALYANI, D. C.; GOVINDWAR, S. P. Decolorization and detoxification of sulfonated azo dye methyl orange by Kocuria rosea MTCC 1532. Journal of Hazardous Materials, v. 176, n. 1, p. 503-509, 2010. https://doi.org/10.1016/j.jhazmat.2009.11.058

PINHEIRO, H. M.; TOURAUD, E.; THOMAS, O. Aromatic amines from azo dye reduction: status review with emphasis on direct UV spectrophotometric detection in textile industry wastewaters. Dyes and Pigments, v. 61, n. 2, p. 121-139, 2004. https://doi.org/10.1016/j.dyepig.2003.10.009 
PRASAD, A. S. A.; RAO, K. V. B. Aerobic biodegradation of Azo dye by Bacillus cohnii MTCC 3616 an obligately alkaliphilic bacterium and toxicity evaluation of metabolites by different bioassay systems. Applies Microbiology and Biotechnology. v. 97, n. 16, p. 7469-7481, 2013. https://doi.org/10.1007/s00253-012-44923

PUNZI, M.; ANBALAGAN, A.; BÖRNER, R. A.; SVENSSON, B-M.; JONSTRUP, M.; MATTIASSON, B. Degradation of a textile azo dye using biological treatment followed by photo-fenton oxidation: evaluation of toxicity and microbial community structure. Chemical Engeneering Journal, v. 270, p. 290-299, 2015. https://doi.org/10.1016/j.cej.2015.02.042

PUVANESWARI, N.; MUTHUKRISHNAN, J.; GUNASEKARAN, P. Toxicity assessment and microbial degradation of azo dyes. Indian Journal of Experimental Biology, v. 44, n. 8, p. 618-626, 2006.

QU, Y.; CAO, X.; MA, Q.; SHI, S.; TAN, L.; LI, X.; ZHOU, J. Aerobic decolorization and degradation of Acid Red B by a newly isolated Pichia sp TCL. Journal of Hazardous Materials, v. 223, p. 31-38, 2012. https://doi.org/10.1016/j.jhazmat.2012.04.034

RAI, H. S.; BHATTACHARYYA, M. S.; SINGH, J.; BANSAL, T. K.; VATS, P.; BANERJEE, U. C. Removal of dyes from the effluent of textile and dyestuff manufacturing industry: a review of emerging techniques with reference to biological treatment. Critical Reviews in Environmental Science and Technology, v. 35, n. 3, p. 219-238, 2005. https://doi.org/10.1080/10643380590917932

RAMALHO, P. A.; CARDOSO, M. H.; CAVACO-PAULO, A.; RAMALHO, M. T. Characterization of azo reduction activity in a novel ascomycete yeast strain. Applied and Environmental Microbiology, v. 70, n. 4, p. 2279-2288, 2004. https://doi.org/10.1128/AEM.70.4.2279-2288.2004

SHAH, M. P.; PATEL, K. A. Microbial decolorization and degradation of Remazol Black \& Mordant Orange by microbial consortia isolated from common effluent treatment plant. International Journal, v. 2, n. 3, p. 117-124, 2014.

SAMPAIO, J. P.; GADANHO, M.; SANTOS, S.; DUARTE, F. L.; PAIS, C.; FONSECA, A.; FELL, J. W.; Polyphasic taxonomy of the basidiomycetous yeast genus Rhodosporidium: Rhodosporidium kratochvilovae and related anamorphic species. International Journal of Systematic and Evolutionary Microbiology. v. 51, p. 687-697, 2001. https://doi.org/10.1099/00207713-51-2-687

SARATALE, R. G.; SARATALE, G.D.; CHANG, J.S.; GOVINDWAR, S.P. Ecofriendly degradation of sulfonated diazo dye CI Reactive Green 19A using Micrococcus glutamicus NCIM-2168. Bioresource Technology, v. 100, n. 17, p. 3897-3905, 2009. https://doi.org/10.1016/j.biortech.2009.03.051

SAVIN, I. I.; BUTNARU, R. Wastewater characteristics in textile finishing mills. Environmental Engineering and Management Journal, v. 7, n. 6, p. 859-864, 2008.

SELVAM, K.; SWAMINATHAN, K.; CHAE, K. S. Decolourization of azo dyes and a dye industry effluent by a white rot fungus Thelephora sp. Bioresource Technology, v.88, n.2, p.115-119, 2003.

https://doi.org/10.1016/S0960-8524(02)00280-8

SHUKLA, P.; YADAV, N. K.; SINGH, P.; BANSODE, F. W.; SINGH, R. K. Phenylhydrazine induced toxicity: a review on its haematotoxicity. International Journal of Basic and Applied Medical Sciences, v.2, p. 86-91, 2012.

SOLÍS, M.; SOLÍS, A.; PÉREZ, H. I.; MANJARREZ, N.; FLORES, M. Microbial decolouration of azo dyes: a review. Process Biochemistry, v. 47, n. 12, p. 1723-1748, 2012.

https://doi.org/10.1016/j.procbio.2012.08.014 
TAN, L.; NING, S.; ZHANG, X.; SHI, S. Aerobic decolorization and degradation of azo dyes by growing cells of a newly isolated yeast Candida tropicalis TL-F1. Bioresource Technology, v. 138, p. 307-313, 2013. https://doi.org/10.1016/j.biortech.2013.03.183

TELKE, A.; KALYANI, D.; JADHAV, J.; GOVINDWAR, S. Kinetics and mechanism of Reactive Red 141 degradation by a bacterial isolate Rhizobium radiobacter MTCC 8161. Acta Chimica Slovenica, v. 55, n. 2, p. $320,2008$.

TONY, B. D.; GOYAL, D.; KHANNA, S. Decolorization of textile azo dyes by aerobic bacterial consortium. International Biodeterioration \& Biodegradation, v. 63, n. 4, p. 462-469, 2009. https://doi.org/10.1016/j.ibiod.2009.01.003

TRIPATHI, A.; SRIVASTAVA, S. K. Biodegradation of orange $\mathrm{G}$ by a novel isolated bacterial strain Bacillus megaterium ITBHU01 using response surface methodology. African Journal of Biotechnology, v. 11, n. 7,p. 1768-1781, 2014.

VON SPERLING, M. Introdução à qualidade das águas e ao tratamento de esgotos. Editora UFMG, 1996.

YANG, Q.; YEDILER, A.; YANG, M.; KETTRUP, A. Decolorization of an azo dye, Reactive Black 5 and MnP production by yeast isolate: Debaryomyces polymorphus. Biochemical Engineering Journal, v. 24, n. 3, p. 249-253, 2005. https://doi.org/10.1016/j.bej.2004.12.004

YANG, Q.; TAO, L.; YANG, M.; ZHANG, H. Effects of glucose on the decolorization of Reactive Black 5 by yeast isolates. Journal of Environmental Sciences, v. 20, n. 1, p. 105-108, 2008.

https://doi.org/10.1016/S1001-0742(08)60016-9

YU, Z; WEN, X. Screening and identification of yeasts for decolorizing synthetic dyes in industrial wastewater. International Biodeterioration \& Biodegradation, v. 56, n. 2, p. 109-114, 2005. https://doi.org/10.1016/j.ibiod.2005.05.006

WAGHMODE, T. R.; KURADE, M. B.; GOVINDWAR, S. P. Time dependent degradation of mixture of structurally different azo and non azo dyes by using Galactomyces geotrichum MTCC 1360. International Biodeterioration \& Biodegradation, v. 65, n. 3, p. 479-486, 2011. https://doi.org/10.1016/j.ibiod.2011.01.010

WANG, H.; ZHENG, X. W.; SU, J. Q.; TIAN, Y.; XIONG, X. J.; ZHENG, T. L. Biological decolorization of the reactive dyes Reactive Black 5 by a novel isolated bacterial strain Enterobacter sp. EC3. Journal of Hazardous Materials, v. 171, n. 1, p. 654-659, 2009. https://doi.org/10.1016/j.jhazmat.2009.06.050 